\title{
DIGITAL TECHNOLOGIES IN LOGISTICS
}

\author{
Yana Koleshnia ${ }^{1}$, Hanna Zhaldak ${ }^{2}$ \\ ${ }^{1,2}$ National Technical University of Ukraine "Igor Sikorsky Kyiv Polytechnic Institute" \\ Faculty of Management and Marketing
}

\begin{abstract}
The article highlights the attempt to interpret the concept of digital logistics, which in most scientific papers is considered not as a separate concept, but as a set of technologies that allow digitalization of logistics. The main goal of the study is to review key technologies that allow us to talk about the digital transformation of logistics and its digitalization. In particular, the methods and advantages of using technologies such as the Internet of Things, RFID technology, wireless sensor networks (WSN), which are used in an integrated manner and make it possibleto track the movement of goods and apply smart management; digital duplicates that simulate real objects, in particular, warehouses in digital format; autopilot cars, drones, which minimize human participation in the processes of delivery and transportation; blockchain, Big Data, Data Lakes, artificial intelligence, which together allow to form arrays of information and make conclusions and forecasts based on them, which allow optimizing logistics processes; $3 \mathrm{D}$ printing, which makes it possible to replace the delivery of components with their production on-site as needed. Technology such as digital logistics platforms that can be used to optimize procurement and transportation of goods is singled out. Research methodology: analysis and synthesis - for preliminary analysis with the formulation of problems, definition of goals, system approach - for definition of structural connections between elements of digital technology of logistics.
\end{abstract}

Keywords: digital logistics, digital technologies, digital transformation, digitalization, logistics

DOI: 10.17512/znpcz.2021.3.04

\section{Introduction}

Digitization, digitalization, and digital transformation have become trends in modern life and business. Technical inventions and achievements penetrate all areas of business, changing the principles of management and decision-making. There is a transition to a digital economy, where such factors as knowledge and competencies, adaptability to the use of modern technologies, the use of data as a new "specific" resource for value creation come to the fore. This trend has not escaped logistics - today the concept of digital logistics is being formed, and digital technologies are used to minimize logistics costs, including the cost of the "last mile".

Scientists study the impact of digitalization on the logistics chain (Trushkina, Rynkevich 2019), propose definitions, and form a list of components of digital logistics (Afanasenko, Borisova 2019). Some researchers link digital logistics to IT solutions and IT platforms (Bubnova, Levin 2017). Many works are devoted to

${ }^{1}$ Yana Koleshnia, PhD, koleshnia.yana@gmail.com, ORCID: 0000-0002-4856-4898

${ }^{2}$ Hanna Zhaldak, PhD, ann17@i.ua, ORCID: 0000-0003-3421-3648 
highlighting the role and importance of certain technologies in logistics (Zagursky 2020; Armstrong 2020; Veresklya, Mykhalytska 2020; Orda, Udovichenko 2020).

However, despite the relevance of this issue, there is no final definition of the concept of "digital logistics", and information on the digitalization of logistics processes needs to be deepened and systematized.

However, there are still many open issues both in the formation of the conceptual framework and the systematization of information on the use of digital technologies in logistics, in particular during the pandemic and quarantine restrictions.

In accordance with the outlined issues, the authors' main goal is to formulate own definition of the concept of "digital logistics" and systematize information on the use of digital technologies in logistics.

\section{Methods}

During the work general and special research methods were used: analysis and synthesis - to conduct preliminary analysis and define problems, definition of goal to research peculiarities of modern realities of logistics development, system approach - to define structural connections between elements of digital technology of logistics.

\section{Transport and logistics activities in Ukraine}

Transport and logistics activities in Ukraine lag behind other areas in terms of digital transformation and global trends in general. It should be noted that digital transformation in this case should not be equated with digitization or digitalization (Koleshnya, Dergacheva 2020, pp. 283-284).

Significant influence on changes in transport and logistics activities has occurred in recent years. Indeed, most companies have already been able to reorganize their work in some way and adapt their activities to unforeseen changes. With the development of technology and e-commerce and the growing level of digital literacy among consumers, the global industry has changed significantly in recent years. In some industries, the decline in demand for international logistics services during peak periods reached $40-50 \%$ (building materials, metallurgy), but there are also industries where there was an increase of $20-30 \%$ (water, beverages; FMCG).

But despite such significant advances in international logistics, researchers have found that most traditional transport and logistics companies still use manual labor and use available assets inefficiently (on average, $50 \%$ of trucks return empty after delivery). Most logistics companies, in turn, do not use their resources optimally (for example, the average vehicle load is $70 \%$; the share of idle travel-10\%) (Trushkina, Rynkevich 2019, pp. 66-67).

In such realities, the task of minimizing logistics costs becomes more complex and requires the use of new approaches and new technologies that would provide an opportunity to optimize logistics flows and improve the information flows that correspond to them. 
Digital logistics is most often considered by domestic scientists as a complex concept that includes various tools, methods, and techniques of digital optimization and transformation. The definition of this concept was proposed by Afanasenko and Borisova (2019, pp. 20-21). According to them, digital logistics is a part of logistics functions and operations in which digital transformations with the use of information and communication technologies have taken place. It is both a separate type of economic activity and an independent area in the full system of logistics. According to Bubnova and Levin (2017, p. 74), digital logistics should be based on IT support of harmonized systems and production, trade, and economic processes for the movement of goods, material flows in the chains of value creation.

That is, we can say that digital logistics is an independent field or functional area of the enterprise, which is based on the formation of digital flows and the use of digital transformation technologies to build an efficient logistics chain. It can also be added that digital logistics is a type of logistics where the use of modern digital technologies is an important resource.

First of all, we can talk about digitalization in data transmission and information flows that accompany the material flow. Yes, you can digitize and digitalize paperwork, data transfer, communication with contractors and thus improve the speed of information transfer within the logistics chain, but this does not mean digital transformation. In fact, the set of technologies that can be used in logistics is much wider and should change not only the flow of information but also the flow of material.

As known, in terms of the transitivity rate, our country is a leader in Europe. But in terms of logistics efficiency ratios (LPI), Ukraine occupies an outsider position. The quantitative evaluation of logistics efficiency criteria once again emphasizes the importance of digitalization of logistics and the development of its infrastructure.

Digital transformation technologies today include VR / AR technologies, 3D printing, cobots, Big Data, cloud computing, the Internet of Things, digital duplicates, machine learning, artificial intelligence, blockchain, autopilots, RFID, and more. All these technologies can be used in various logistics areas. Let us consider briefly the possible directions of their use.

One of the most frequently mentioned technologies is the Internet of Things (IoT). The "Internet of Things" is considered to be the technology of data transmission between material objects that are interconnected by a network for seamless interaction within the system and with its external entities (Evtodieva et al. 2019). The key advantage of this technology is the ability to constantly monitor, analyze and control changes at each stage of the system. This, in turn, provides an opportunity to conduct a detailed analysis of work gaps at certain stages of movement of a particular unit (machine, product, pallets), to forecast them in the future, and to prevent certain negative scenarios. The availability and accessibility of information about the objects of the "Internet of Things" provides an opportunity to form and reflect the main trends and changes and to analyze the situation, taking into account previous decisions in similar situations of similar entities.

This technology makes it possible not only to track the location of goods in realtime (for example, we can track the movement of a car with cargo in the company Nova Poshta) but also to carry out optimization at a higher level - at the level of 
transport networks in the city or region. Thanks to the network of connections between material objects, it is possible to track road traffic and congestion - and either rebuild the route or regulate urban traffic flows (switch traffic lights, restrict traffic, etc.).

Another advantage of using the Internet of Things is the reduction of storage costs due to smart management with the use of power consumption control, ventilation modes, LED lighting, and control of increasing or decreasing the level of illumination of warehouses depending on the activity inside the territory. This adaptation of technology in warehousing logistics reduces overall costs and contributes to the preservation of the external environment.

The main technology for the Internet of Things is RFID technology, which allows the microchip to transmit the identification information to readers via wireless communication. With RFID readers, people can identify, track and monitor any objects that are automatically connected using RFID tags. RFID technology is widely used in production, warehouse management, transport logistics and measurement of product authenticity, etc. The second technology for IoT is wireless sensor networks (WSNs), which mainly use interactive intelligent sensors (sensors) for collaboration and monitoring. The scope of their application includes environmental monitoring, production control, traffic monitoring, etc. (Zagursky 2020, p. 34).

The information received through the "Internet of Things" technology allows to create "digital duplicates" - digital models of terminals, warehouses, and other objects and to trace in real-time their condition, correctness of functioning, absence of interruptions and problems, and in the case of the latter - to maximally automate their solutions

Digital duplicates are the virtual equivalent of a real physical product or service. Many large companies now use digital duplicates to monitor the status of production equipment in real-time, analyze changes in key parameters and take measures to perform conditional or predictive maintenance based on the smallest deviations (Armstrong 2020). Digital duplicates can be created both for individual parts and for entire complexes - for example, customs terminals, warehouses. The system of sensors, which constantly transmit the parameters of the environment to the computer, allows online monitoring of important parameters, such as temperature, humidity, air pollution, and timely adjustments. The ability to automatically adjust important storage conditions for perishable products or goods that require strict adherence to such conditions allows you to significantly minimize product losses.

Autopiloted cars today, although not fully autonomous on the roads, are not new. For example, truck companies (such as Volvo) have long proposed technology that allows a convoy of driverless cars to follow the first car in the convoy. However, gaps in legislation today prevent the full introduction of autopilot devices.

The use of drones to deliver goods to consumers is quite close. Tests of drones as a method of delivery are conducted around the world. One of the best-known companies to launch this innovation is Amazon.com, the largest e-commerce company in the United States. The work on the Amazon Prime Air project began in 2013. It involves the delivery of goods to customers using octocopters (drones with 8 propellers). Among Ukrainian enterprises, this type of cargo transportation was 
considered by Nova Poshta (Mueller 2020, p. 101). In a global pandemic, such technology is particularly relevant, but for Ukraine it is expensive and faces a lack of regulation. However, drones are used in agriculture - they monitor the condition of the fields, and with the help of information obtained from drones, digital duplicates of the fields are formed. This technology is used by Kernel.

One of the most common technologies used, including in logistics, to form reliable and transparent supply chains is the blockchain. The term blockchain literally means "chain of blocks", where each block is related to the previous one. A block is an information package that contains all the previous information and some new ones. And the whole chain is a database distributed between many participants, operating without centralized management, i.e., there is no intermediary in the form of a single "central server", which stores all the information. Lack of centralization is an important element of technology, as all data is stored on users' computers. All users of the chain are equal and form a network of computers, each of which stores a copy of blockchain data (Veresklya, Mykhalytska 2020, p. 101).

The advantage of this technology is that the information stored in the chain cannot be changed or deleted. All the stages that take place, for example, the cargo when moving from supplier to customer in international logistics, are recorded using a blockchain. Errors, inconsistencies in the documents are immediately tracked, which makes it possible to identify the person responsible for losses or expenses.

Blockchain technology is expected to increase the world GDP by $5 \%$ and international trade by $15 \%$. Blockchain-based product tracking schemes, such as Waltra's Food Traceability Initiative, will ensure full transparency and traceability of products along the entire route of the product. With the help of the blockchain, one can perform automatic billing and payment, and the payment will be processed as soon as the goods arrive at the destination (Kopyshynska 2020). For the transportation of food, medicines, the blockchain allows you to track and analyze all the parameters that may affect the quality of products and thus ensure the safety of the product for the final consumer. Moreover, such information can be encrypted in QR-codes and be available to the buyer directly in the store - by scanning the code the customer can determine the product manufacture date, the temperature of its storage, and so on. The blockchain for tracking deliveries and quality of deliveries is used by TradeLens, the IBM Food Trust project (the project includes such well-known companies as Nestlé, Unilever and Walmart Everledger, Vinturas).

The blockchain and the Internet of Things generate significant amounts of information in a variety of formats. It is accompanied by current reports, accounting information, management information, analytical data of departments. All these form a set of structured and unstructured data that needs to be processed. Such data is called Big Data and is also an important technology. It is often accompanied by artificial intelligence (AI) because it is difficult for a person to capture and process large amounts of rapidly changing information.

Data is the most valuable "commodity" in the world. Big Data helps to revolutionize the business models of enterprises. The use of AI has simplified demand forecasting, route optimization, enabled risk management, and the use of forecasting 
analytics. Thus, the costs of the enterprise are reduced by an average of $49 \%$, and the implementation of new smart solutions occurs in $44 \%$ of cases (information from the Big Data Executive report) (Kopyshynska 2020).

Ultimately, Big Data is expected to be able to change the logistics business model from reactive to predictive. Forecasting analytics uses data from online suppliers to predict sharp jumps in sales, which means that the supplier can send an additional batch of goods as soon as necessary (Kopyshynska 2020).

Storing large amounts of information requires a lot of information space, and most often today clouds are used to store a variety of data. Moreover, entire software can be transferred to the cloud.

Cloud logistics is fast becoming popular: $50 \%$ of logistics service providers already use cloud services, $20 \%$ plan to do so. As data is transferred to the cloud, logistics services become available as part of the on-demand payment. This means that small businesses no longer need to spend on comprehensive IT solutions. They pay only for what they need and when they need it. Services such as Shipwire and Freightly provide real-time cloud traffic management systems. They cover all logistics processes from procurement to invoicing, which makes the whole process easier and cheaper for companies (Kopyshynska 2020).

Logistics is characterized by the use of data lakes. A data lake is an element of the Big Data infrastructure, a repository of large amounts of structured and unstructured data generated or collected by a single company or government agency, and a way to organize large amounts of diverse data from different sources. Data in lakes are stored, as a rule, in an unsystematized form. However, they make it possible to work with different types of data, such as unstructured, semi-structured, and complex. Data lakes can be located on the company's servers or in cloud storage (Orda, Udovichenko 2020, p. 213).

An example of a company using a set of technologies - blockchain and artificial intelligence - is the startup Yojee (Singapore). The technology platform, which provides powerful logistics capabilities in supply chain management, uses artificial intelligence and blockchain technology. The platform replaces the manager, monitors the status of orders in real-time, generates invoices, and manages tasks. The scope of the platform is thirty thousand vehicles and customers from Singapore, Australia, Cambodia, and Indonesia (Zhaldak 2021).

3D printing is a technology that, at first glance, is more related to the production process than to logistics. But replacing the supply of goods with the delivery of the technology itself at the place of demand can reduce the financial and time costs for the supply of materials by reducing the supply chain. The necessary materials can be created on-site at the right time and in the right amount.

It is also worth noting that after the introduction of quarantine measures, logistics for small and medium-sized businesses has become more expensive, in particular, this has led to increased operating costs, as large 3PL providers do not work systematically with small companies. An example of a solution to this problem was the online warehouse management service on-Demand. Using this service provides the following opportunities (my thesis): 
- manage shipment in the warehouse in real-time;

- calculate the cost of services from different providers;

- monitor data on the status of orders;

- monitor the state of stocks in the warehouse;

- control the movement of goods.

It is also important to select the optimal buffer composition for the temporary storage of goods. Recently, there is a need to rent a warehouse for a short period (one or two weeks), mainly on the eve of the holidays, when there are significant peak loads on delivery services, as well as overloading of warehouses. In order not to lose profits due to the absence of goods in the warehouse and the interruption in the supply of goods, experienced managers create reserves of goods and look for additional space for their temporary storage. Now there are special services where you can leave a request for the selection of the warehouse, indicating the number of pallets, locations, and more.

The logistics of the "last mile" has also become especially popular in modern realities. This term is used in the study of logistics operations and supply chain management to describe the movement of goods from the initial node to the final destination. That is, the movement from the zero transport node to the receiver. An important issue is to minimize costs and increase efficiency. If we take into account the international experience, the reduction of delivery time from the city warehouse to the first point of consumption by 10 minutes saves 1 million euros per year (Orda, Udovichenko 2020). The term was first used in the United States, in the field of telecommunications, when companies faced the problem of connecting homes to the main television network, the Internet, and more. Last-mile delivery is now becoming more popular due to the growing demand for online orders. Ukrainian companies are leaders in the level of logistics development in the field of e-commerce.

The most common technologies that are actively used in Ukraine and allow to reduce the cost of the "last mile" are digital logistics platforms. The digital platform itself is a software application or site that accumulates information about the offer of goods and services and provides an opportunity to "meet" the consumer and the supplier (where the user of the platform can be both a consumer and a supplier). Such platforms make it possible to optimize both procurement (tender platforms) and transportation.

Tender platforms, such as Prozorro, make it possible to optimize the search for suppliers in accordance with the requirements - both in terms of price / quality of goods, and in terms of delivery terms. The use of artificial intelligence or machine learning technologies allows you to automate this process and form a list of the most relevant proposals for the company.

Transport platforms make it possible to optimize the loading of cars when transporting goods, to find a carrier by placing a request. An example is Lardi-Trans a large freight exchange. The scale of such platforms allows for international transportation. For the company, this technology allows companies to transport cargo at a minimum price, sharing it with other participants in the "loading" of the car. In general, the traffic load is optimized and the percentage of idling is reduced. 


\section{Conclusions}

The study provided an opportunity to solve the scientific problem of developing theoretical and applied aspects of digital logistics in the pandemic and quarantine restrictions, in particular, to summarize the features of the use of modern digital technologies in logistics. Logistics can take advantage of modern digital technologies, but the main problem is the unpreparedness of both digital infrastructure and transport and logistics infrastructure for the large-scale use of digitalization and digital transformation. The question of the cost of most technologies arises separately. Today, those technologies that require less investment are more widely used clouds, data lakes, Big Data, the Internet of Things (in a rather limited format in terms of capabilities). The main points of scientific novelty revealed in this article include the following: With the changes and the historical course of mankind, there are changes in the place and role of logistics as a management tool. The results of research on the use of digital technologies in logistics are summarized on the basis of deepening theoretical provisions on the application of industry 4.0 technologies in the formation of digital logistics, including during the pandemic and in the increasing demand for logistics services. A promising area of further research is to assess the feasibility of introducing new technologies, in particular, the 5G-Internet, which is not yet used in Ukraine. The quality of transport infrastructure and legal restrictions do not allow the use of autopilot transport. That is why the digitalization of logistics in Ukraine is still a process in its infancy, and therefore many issues of the use of digital technologies in logistics remain open.

Given the active development of digital technologies, further research can be aimed at finding possible ways to use them in logistics not only by influencing the flow of information (data, document flow), but also the transformation of traditional supply chains.

\section{References}

1. Afanasenko I.D., Borisova V.V. (2019), Digital Logistics: A Textbook for Universities, Piter, $\mathrm{SPb}$.

2. Armstrong M.M. (2020), Cheat Sheet: What is Digital Twin?, https://www.ibm.com/blogs/ internet-of-things/iot-cheat-sheet-digital-twin/ (accessed: 19.04.2021).

3. Bubnova G.V., Levin B.A. (2017), Digital Logistics As an Innovative Mechanism for the Development and Effective Functioning of the Transport and Logistics Systems and Complexes, "International Journal of Open Information Technologies", Vol. 5, No. 3, pp. 72-78.

4. Evtodieva T.E., Chernova D.V., Ivanova N.V., Kisteneva N.S. (2019), Logistics 4.0, [in:] Ashmarina S., Vochozka M. (Eds.), Sustainable Growth and Development of Economic Systems, Springer, Cham. DOI: 10.1007/978-3-030-11754-2 16.

5. Koleshnya Ya.O., Dergacheva G.M. (2020), Digital Transformation of Business: Essence, Signs, Requirements and Technologies, "Economic Bulletin of NTUU "KPI"", Vol. 17, pp. 280-290. DOI: 10.20535/2307-5651.17.2020.216367.

6. Kopyshynska K.O. (2020), The Use of Data Lakes as a Component of Digital Transformation of Transport and Logistics Companies, Business, innovation, management: problems and prospects: I International Scientific-Practical Conference, April 23, 2020, IVC Publishing House "Polytechnic", Kyiv, pp. 212-213. 
7. Last mile (transportation), Wikipedia, веб-сайт, https://en.wikipedia. org/wiki/Last_mile_ (transportation) (accessed: 21.05.2021).

8. Mueller A.S. (2020), Delivery by Drones: Prospects, Advantages and Disadvantages, Innovative Ukraine: creative ideas and projects: coll. ext. 87th Scientific Student Conference, May 4-13, Kyiv, KNEU, 410 p.

9. Orda O.O., Udovichenko V.O. (2020), Analysis of Digital Logistics Solutions "Last Mile”, https://dspace.khadi.kharkov.ua/dspace/bitstream/123456789/2889/1/\%D0\%9E\%D1\%80\% D0\%B4\%D0\%B0\%20\%D0\%9E.\%D0\%9E .pdf (accessed: 21.05.2021).

10. Trushkina N.V., Rynkevich N.S. (2019), Digital Logistics As a Tool for Transport and Logistics Companies in Terms of Digitalization, "International Relations", part "Economic Sciences", pp. 1-20.

11. Veresklya M., Mykhalytska N. (2020), The Use of Blockchain Technology in Supply Chains, Collection of scientific works "GO", pp. 17-18, https://www.everest.ua/pyat-klyuchovyh -tehnologij-dlya-czyfrovoyi-transformacziyi-v-logistyczi/ (accessed: 19.04.2021).

12. Zagursky O.M. (2020), The Use of Internet of Things Technology in Supply Chains of Perishable Food Products, https://dspace.khadi.kharkov.ua/dspace/bitstream/123456789/3334/1/10.pdf (accessed: 19.04.2021).

13. Zhaldak H. (2021), Modern Realities of Logistics and Electronic Commerce Development, http://confmanagement.kpi.ua/proc/article/view/231025 (accessed: 21.05.2021).

\section{TECHNOLOGIE CYFROWE W LOGISTYCE}

Streszczenie: W artykule zwrócono uwagę na próbę interpretacji pojęcia logistyki cyfrowej, która w większości prac naukowych traktowana jest nie jako odrębna koncepcja, ale jako zespół technologii pozwalających na cyfryzację logistyki. Głównym celem badania jest przegląd kluczowych technologii, które pozwalają nam mówić o cyfrowej transformacji logistyki i jej digitalizacji - w szczególności metody i zalety korzystania z technologii takich jak Internet Rzeczy, technologia RFID, bezprzewodowe sieci czujników (WSN wireless sensor network), które są wykorzystywane w sposób zintegrowany oraz pozwalają śledzić ruch towarów i stosować inteligentne zarządzanie; duplikaty cyfrowe symulujące rzeczywiste obiekty, w szczególności magazyny w formacie cyfrowym; samochody $\mathrm{z}$ autopilotem, drony, które minimalizują udział człowieka w procesach dostawy i transportu; blockchain, Big Data, Data Lakes, sztuczna inteligencja, które razem pozwalają tworzyć tablice informacji i na ich podstawie wyciągać wnioski i prognozy, co pozwala na optymalizację procesów logistycznych; druk 3D, który pozwala w razie potrzeby zastąpić dostawę komponentów ich produkcją na miejscu. Wyróżniono technologie, takie jak cyfrowe platformy logistyczne, które można wykorzystać do optymalizacji zaopatrzenia i transportu towarów. Metodologia badań zastosowana na potrzeby artykułu to analiza i synteza - do wstępnej analizy z formowaniem problemów, określenie celów, podejście systemowe - do określenia powiązań strukturalnych pomiędzy elementami cyfrowych technologii logistycznych.

Słowa kluczowe: logistyka cyfrowa, technologie cyfrowe, transformacja cyfrowa, cyfryzacja, logistyka 